Journal of Social Sciences (COES\&RJ-JSS)

ISSN (E): 2305-9249 ISSN (P): 2305-9494

Publisher: Centre of Excellence for Scientific \& Research Journalism, COES\&RJ LLC

Online Publication Date: $1^{\text {st }}$ April 2015

Online Issue: Volume 4, Number 2, April 2015

http://www.centreofexcellence.net/J/JSS/JSS Mainpage.htm

\title{
Organizational sustainability in public institutions of higher education. A theoretical - empirical approach
}

\author{
Patricia, García-Hernández ${ }^{\text {a }}$, Patricia, Mercado-Salgado ${ }^{\text {b }}$. \\ ${ }^{a}$ Universidad Autónoma del Estado de México, Centro Universitario UAEM \\ Temascaltepec, Km. 67.6 Carretera Toluca- Tejupilco, Temascaltepec, Estado de México, \\ México, C.P. 51300 \\ ${ }^{\mathrm{b}}$ Universidad Autónoma del Estado de México, Facultad de Contaduría y Administración, \\ Ciudad Universitaria, Cerro de Coatepec, Toluca, Estado de México, México, C.P. 50110
}

\begin{abstract}
Objective: Based on two approaches, the triple bottom line (TBL) and the quadruple bottom line (QBL), this paper aims to (1) identify the components that make up the construct of Organizational Sustainability (OS) in a public institution of higher education (PIHE) and (2) validate those components. Method: A questionnaire called organizational sustainability diagnostic (OSD) was constructed and applied to 239 volunteer subjects, faculty and staff members of a PIHE. Data analysis included qualitative and quantitative test of content and construct validity, and exploratory factor analysis. Results: (1) the construct OS is consistent with the QBL variables (environmental sustainability, social sustainability, financial sustainability and institutional sustainability), and (2) the OSD is a valid and reliable instrument for diagnosing OS in PIHEs. These results require further empirical evidence. A research agenda is proposed to extend the study to other PIHEs, and create tools to assess the construct OS using historical data.
\end{abstract}

\section{Keywords}

Organizational sustainability, public institutions of higher education, triple bottom line, quadruple bottom line.

JEL

I20, I23, Q56

\section{Citation}

García-Hernández, Patricia; Mercado-Salgado, Patricia, (2015); Organizational sustainability in public institutions of higher education. A theoretical - empirical approach; Journal of Social Sciences (COES\&RJ-JSS), Vol. 4, No. 2, pp:867-876.

http://dx.doi.org/10.17632/rywtd2h66d.1 


\section{Introduction}

Public institutions of higher education (PIHE) face an environment that requires quality, modernity and efficiency without neglecting their primary functions: prepare the human and intellectual capital required by society, conduct cutting-edge research and extend the resulting knowledge to the community ${ }^{1}$.

In this scenario, Robinson ${ }^{2}$ and Poldony ${ }^{3}$ argue that an institutional framework is needed to help to create favorable conditions for operation and performance of agents of a university system: teachers, students and administrators. An alternative to this could be the Organizational Sustainability (OS); the core of this research.

The OS comes from a compelling new paradigm: sustainable development whose meaning and content change depending on who uses it. What an ecologist accepts by sustainable development and sustainability is different from the accepted by economist, anthropologist or politician ${ }^{4,5}$.

In essence, there is no consensus on the variables that must be included in the basis construct for the study of sustainability in organizations. To advance the understanding of the phenomenon, this study looks for an answer to the question: which variables comprise the construct OS in a PIHE? In order to answer this, an instrument of primary data collection, called the organizational sustainability diagnostic (OSD) was built. A second research question arises: the OSD is a valid and reliable instrument to diagnose OS in PIHEs?

Most of the criticism for social phenomena measurements is focused on use of invalid instruments, that is, without well-founded theoretical basis ${ }^{6}$. In response to this, the construction of OSD was based on (1) sustainable development paradigm theoretical framework, and its background in the natural, economic and administrative sciences, and (2) previous studies on sustainability in organizations and in institutions of higher education (IHEs).

This article is composed as follows: in the first section; the background of OS on the QBL and TBL and the research hypotheses are posed. The second section is devoted to the method. The results and discussion are presented in the third section, finally conclusions, limitations and future research agenda are exposed.

\section{Theoretical framework and hypotheses}

Sustainability in organizations is a complex phenomenon, it cannot be analyzed in a simplistic and linear way, so this study uses abduction of TBL components, which considered economic, social and environmental dimension of sustainability ${ }^{7}$.

TBL abduction is supported by Barbieri et. al. ${ }^{8}$, they argue that components of sustainable development are equivalent to components of sustainability in organizations. Although TBL is a holistic approach to sustainability, it lacks guidelines for putting it into practice $^{4}$. This needs the inclusion of the institutional component, with regulations and regulatory structures that contribute to the operation of sustainability. This raises the QBL that consists of social sustainability, environmental sustainability, economic sustainability and institutional sustainability ${ }^{9,10}$.

The QBL of OS is supported by institutional theory (IT) and Resources Dependency Theory (RDT). In accordance with IT, organization's survival and legitimacy requires institutional and moral fortitude ${ }^{11,12}$, so they must incorporate social, environmental and financial interests of present and future stakeholders ${ }^{13}$.

Social sustainability reflects the organization's involvement in social issues, and refers the ability to build healthier, more equitable, diverse, connected and democratic community, providing good quality of life for present and future generations ${ }^{14,15}$. Social sustainability requires society cohesion, exclusion and discrimination aversion, citizen 
participation in public affairs and poverty reduction ${ }^{16}$. Social sustainability is an anthropocentric issue claiming the right to a decent life for present (intragenerational justice) and future (intergenerational justice) human communities ${ }^{17}$. Intragenerational justice implies inclusion of disadvantaged groups in making decisions that affect social, ecological and economic issues, intergenerational justice considers the costs of development on the demand for future generations ${ }^{16}$.

Environmental sustainability includes impacts for biotic and non-biotic natural resources use, and emission of pollutants generated by organization operation ${ }^{18}$. Environmental sustainability refers to rational use of biophysical resources, including care of air, soil and water quality, and conservation of biodiversity ${ }^{9}$. The purpose of these actions is to maintain natural capital as a resource and as a dumping ground for waste generated $^{19}$. Environmental sustainability is pursued not for its intrinsic importance, but to improve the welfare and prevent harm to human, making clear once again the anthropocentric nature of sustainability ${ }^{20}$.

In this paper the term economic sustainability is replaced by financial sustainability, because the organizations analyze their performance from financial indicators $^{21,22}$. Financial sustainability refers ability to manage financial capital to generate wealth and prosperity for public interest, which should be shared between current and future generations ${ }^{23}$. Organizational sustainability requires preservation and increase of financial capital, and financial self-sufficiency ${ }^{11}$. Good financial performance and spills of benefits to stakeholders help to improve the reputation and legitimacy of the organization $^{21}$.

Institutional sustainability is the fourth component and it refers to the systems, formal and informal processes, and structures that manage human, material and financial resources to support the goals of sustainability in organizations ${ }^{22}$. Institutional sustainability is supported by RDT, this theory posits that organizations are not selfsufficient, to grow and survive depend on the human, natural and financial resources taken from the environment. The organization seeks to reduce this dependency handling transactions with its stakeholders and ensuring access to scarce and valuable resources ${ }^{24}$. The relationships between the organization and stakeholders are regulated by institutional structures managed by boards. Thus, the survival of the organization is contingent upon the ability of its boards to control these structures and reduce dependence ${ }^{25}$.

The QBL has been adopted for the study of sustainability in different kinds of organizations, including IHEs. Table 1 summarizes the variables proposed in the literature. The last column shows the variables proposed in this paper for the OSD construction. 
Table 1. Sustainability components

\begin{tabular}{|c|c|c|c|c|}
\hline Model & $\begin{array}{c}\text { Sustainable } \\
\text { development* }\end{array}$ & $\begin{array}{l}\text { Sustainability } \\
\text { in } \\
\text { organizations** }\end{array}$ & $\begin{array}{l}\text { Sustainability } \\
\text { in IHEs**** }\end{array}$ & $\begin{array}{l}\text { Organizational } \\
\text { sustainability } \\
\text { (proposal) }\end{array}$ \\
\hline \multirow{3}{*}{ 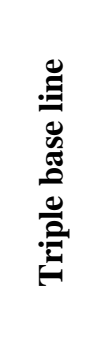 } & Social & Social & Social & Social sustainability \\
\hline & Environmental & $\begin{array}{c}\text { Environmental } \\
\text { Physical- } \\
\text { biological }\end{array}$ & Environmental & $\begin{array}{l}\text { Environmental } \\
\text { sustainability }\end{array}$ \\
\hline & Economics & $\begin{array}{l}\text { Economics } \\
\text { Financial }\end{array}$ & Economics & Financial sustainability \\
\hline \multirow{4}{*}{ 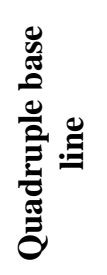 } & \multirow{4}{*}{ Institutional } & \multirow{4}{*}{ Policy } & $\begin{array}{c}\text { Philosophical- } \\
\text { Political }\end{array}$ & \multirow{4}{*}{ Institutional sustainability } \\
\hline & & & Planning & \\
\hline & & & Academic & \\
\hline & & & Research & \\
\hline
\end{tabular}

Source: Prepared based on * UNCSD, $1992^{7}$; UNCSD, 2001 $; * *$ Ekington, $1997^{26}$; Achkar, 2005 $5^{18}$; Firestone, Hadders, \& Cavaleri, $2009^{27}$, *** Gutiérrez \& Martínez, 2009 ${ }^{28}$; Garza \& Medina, 2010² ; Wigmore \& Ruiz, 2010

From the above emerges the following hypothesis: $H_{0}$ : OS components in PIHE are consistent with the components of the QLB.

\section{Method}

\subsection{Construction and validation of $O S D$}

In order to design the OSD, qualitative and quantitative techniques were applied (figure 1). An initial questionnaire (159 items) was evaluated by three experts groups, who judged the content validity based on items representativeness and relationship with the theoretical foundations of organizational sustainability. From this evaluation, a questionnaire of 78 items (called OSD-78) was obtained, in accordance with expert's opinion; these items measure what they claim to measure. This questionnaire was applied in a survey; data obtained were used in quantitative construct validity and internal consistency test.

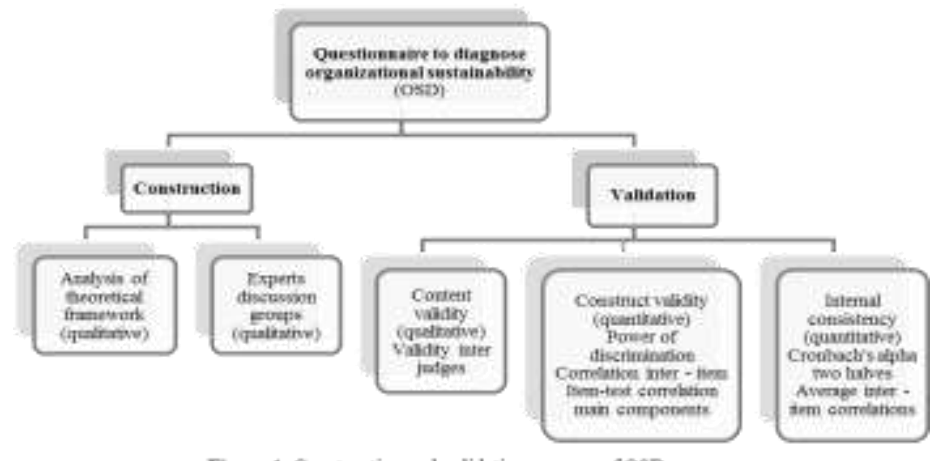

Figare 1. Construction and validation process of OSD 


\section{Organizational sustainability in public institutions.....}

\subsection{Population, analysis unit and data collection}

The OSD-78 was applied in a PIHE. Analysis units were: academic, directors and staff from 50 academic areas (nine high school campuses, 21 faculties and 20 research centers and institutes) belonging to a Mexican public university.

Online survey was conducted from July 10 to September 8, 2012. One drawback of online surveys is the low response rate, which may be less than $20 \%$, this is offset by bulk mail ${ }^{31}$. In care of this, 4,401 invitations for participation were sent by email. In the message, the purpose of the survey was explained, the anonymity was emphasized and the league website annexed to access the online questionnaire. As an incentive to those who complete the questionnaire, respondents participated in a raffle for five portable solar chargers.

The non-probabilistic sample comprised 239 subjects (academic, administrative workers and directors), from 41 of the 50 existing academic areas in PIHEs taken as study laboratory. Respondent's ages ranged from 23 to 79 years, with a mean of 41 and mode of 50 years. $52.7 \%$ were men, $38.1 \%$ were full-time faculty, $37.7 \%$ were part-time academics, $20.1 \%$ were administrative staff, and $4.2 \%$ directors; $75 \%$ with postgraduate studies (43.9\% master's degree, $24.7 \% \mathrm{PhD}$ and $6.3 \%$ with specialization studies).

\section{Results and discussion}

To extract the underlying factors from data matrix, an exploratory factor analysis (EFA) was performed using principal components extraction with Varimax orthogonal rotation. The suitability of the data matrix to apply a factor analysis was checked with Kaiser-Meyer-Olkin test of adequacy $(\mathrm{KMO}=0.927)$ and the Bartlett test of sphericity $(\mathrm{p}$ $<0.000)$.

Initial extraction yielded 17 components; the explained variance was 68\% (table 2). According Morales ${ }^{32}$ criterion, components 1,2 are solidly defined with six items that load weights greater than 0.5 . Components $3,4,5,6,7,8,11$ are well defined with at least three items that loads weights greater than 0.5 . The components $9,10,12,14$ have only two items (minimum number to discuss things in common) with weights greater than 0.5 ; components $13,15,16,17$ have only one item, insufficient to analyze their relationship with other components.

First EFA results in 33 removed items: 25 items with factor loads lower than 0.5 $(1,5,7,10,15,18,24,25,29,30,35,41,44,45,46,47,52,53,58,62,63,65,66,67,69)$; and eight items belonging to weakly defined factors with only two items $(39,40,54,55$, $56,57,64,68$,).

A second EFA was conducted for the remained 45 items, confirming the requirements of the correlation matrix $(\mathrm{KMO}=0.922$ and Bartlett test of sphericity $\mathrm{p} \leq$ .000 ). Eleven factors were obtained, explained variance increased to $69.91 \%$. Items 2,4 , 20,37 loaded lower than 0.5 , and items 3,48 belonged to factors with only one, so were deleted. The resulting OSD, hereinafter referred OSD-39, is composed of 39 items grouped into 9 components named according their content (table 3).

Reliability was assessed using Cronbach's alpha (table 3). According to Hogan ${ }^{33}$, acceptable reliability coefficient depends on the purpose and type of decision derived from the test. Decisions affecting an individual require acceptable and desirable reliability coefficients ( 0.90 to 0.95$)$, a test for other research purposes accept a moderate reliability of 0.70 to 0.80 . For García ${ }^{34}$ minimum acceptable value is 0.50 . All resulting components showed high alpha coefficients. These indices shows a high degree of consistency in the responses of the participants, the items covary strongly with each other and contribute to gauge what measures the questionnaire. This homogeneity is achieved only if the group of reactive measures the same construct or content domain ${ }^{35}$. 
The OSD - 39, meets the requirements of validity and internal consistency for the diagnosis of OS in PIHEs. So far, the results support the hypotheses proposed in this research, since the components of the OS in a PIHE are consistent with the components of the QBL.

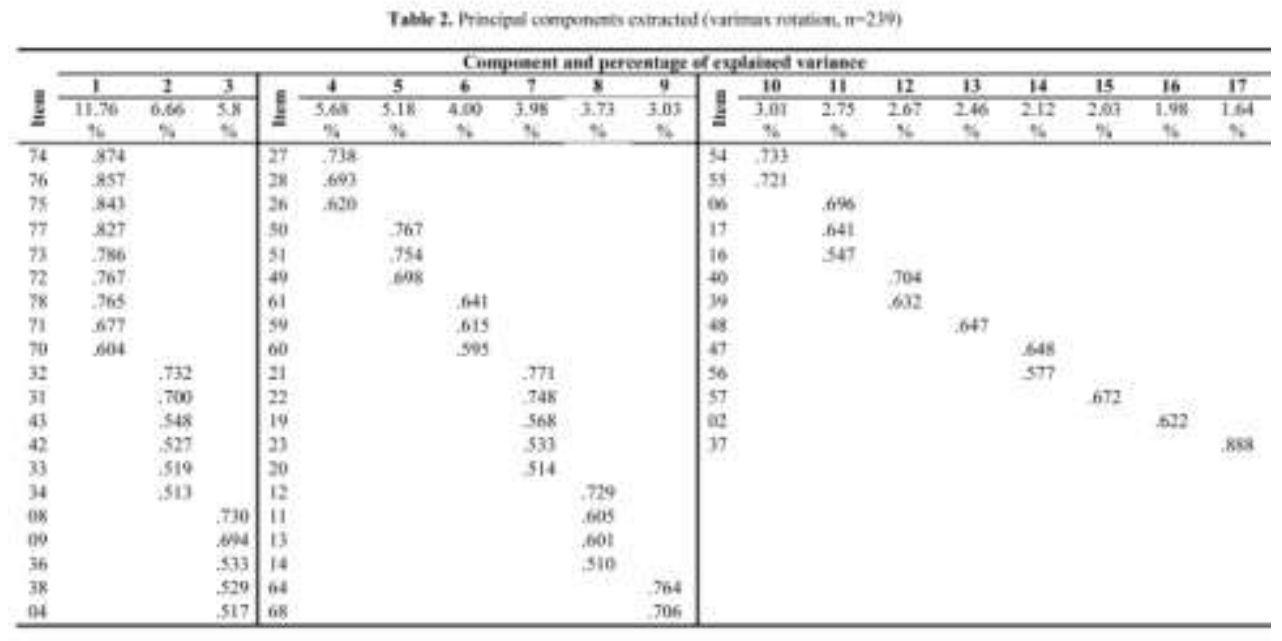

Table 3. Components and items of the OSD-39

\begin{tabular}{|c|c|c|c|c|c|}
\hline QBL variable & $\begin{array}{c}\text { OSD-39 } \\
\text { component }\end{array}$ & $\begin{array}{c}\text { Percentage } \\
\text { of } \\
\text { explained } \\
\text { variance }\end{array}$ & $\begin{array}{l}\text { Cronbach's } \\
\text { alpha }\end{array}$ & Items & Quantity \\
\hline $\begin{array}{c}\text { Institutional } \\
\text { sustainability }\end{array}$ & $\begin{array}{l}\text { trategies and } \\
\text { functions for } \\
\text { sustainability }\end{array}$ & 16.602 & 0.952 & $\begin{array}{c}\mathbf{7 0 , 7 1}, \\
\mathbf{7 2 ,} \mathbf{7 3}, \\
\mathbf{7 4 ,} \mathbf{7 5}, \\
\mathbf{7 6 , 7 7}, \\
\mathbf{7 8}\end{array}$ & 9 \\
\hline $\begin{array}{c}\text { Social } \\
\text { Sustainability }\end{array}$ & $\begin{array}{l}\text { Puality of life in } \\
\text { the organization }\end{array}$ & 9.066 & 0.876 & $\begin{array}{c}\text { 31, 32, } \\
\text { 33, } \\
\text { 34,42, } 43\end{array}$ & 6 \\
\hline $\begin{array}{c}\text { Social } \\
\text { Sustainability }\end{array}$ & Iealthy campus & 6.856 & 0.752 & $8,9,36,38$ & 4 \\
\hline $\begin{array}{c}\text { Social } \\
\text { sustainability }\end{array}$ & $\begin{array}{l}\text { quity and } \\
\text { diversity }\end{array}$ & 6.425 & 0.800 & $\begin{array}{c}19, \\
21,22,23\end{array}$ & 4 \\
\hline $\begin{array}{c}\text { Financial } \\
\text { sustainability }\end{array}$ & $\begin{array}{l}\text { vailability of } \\
\text { financial and } \\
\text { material } \\
\text { resources }\end{array}$ & 5.897 & 0.857 & $49,50,51$ & 3 \\
\hline $\begin{array}{l}\text { Environmental } \\
\text { sustainability }\end{array}$ & $\begin{array}{l}\text { Rs activities } \\
\text { (reduce, reuse, } \\
\text { recycle) }\end{array}$ & 5.659 & 0.766 & $\begin{array}{l}11,12 \\
, 13,14\end{array}$ & 4 \\
\hline
\end{tabular}


Organizational sustainability in public institutions.....

\begin{tabular}{c|l|c|c|c|c}
$\begin{array}{c}\text { Social } \\
\text { sustainability }\end{array}$ & bonding & 5.626 & 0.896 & $26,27,28$ & 3 \\
$\begin{array}{c}\text { Environmental } \\
\text { sustainability }\end{array}$ & $\begin{array}{l}\text { missions and } \\
\text { waste } \\
\text { management } \\
\begin{array}{c}\text { Institutional } \\
\text { sustainability }\end{array}\end{array}$ & 4.203 & 0.703 & $6,16,17$ & 3 \\
\hline
\end{tabular}

\section{Conclusions}

This research supports theoretically and empirically the construct OS based on QBL. The theoretical background support the QBL as superior to TBL. QBL integrates institutional sustainability as the variable that manages the organizational actions to achieve OS, and from the DRT perspective, institutional sustainability legitimizes organization in society ${ }^{36}$. In addition, institutional sustainability is the second contributor to the construct variance, suggesting its influence in achieving organizational sustainability in PIHEs.

Empirical evidence shows OSD-39 based on QBL is a valid and reliable instrument, the errors obtained in the application are more related to the conditions in information collection, but not with instrument deficiencies. OSD-39 is an extensive questionnaire, but it's a good alternative to other instruments compounded with a number of even more items.

The limitations of this study relate to (1) the lack of evidence to support or exclude alternative explanations for the main findings, and (2) limitations of the research design, which took only one organization to collect data; so, results are applicable only to the of study subject.

The lack of background and empirical evidence to support or refute these results, open a research agenda that addresses the following:

- The OS is an organizational variable, so future research should extend to reach other organizations. This research may be expanded to include other PIHEs similar to that taken as a research laboratory.

-The OS by definition is observable in the long term, future research may arrogate to create tools to assess the construct OS from historical data and secondary sources.

Finally, more than thirty years after the discussion on the paradigm of sustainable development entered to the scientific scene, we still find that there is no consensus on how to implement it. Understandably, a construct derived from this paradigm, such as the OS, present more questions than answers. The OS provides extensive research opportunities for scholars interested in an issue that goes beyond fashion or convenience; OS legitimizes the actions of organizations to present and future generations.

\section{References}

1. P. A. David, D. Foray, "Una introducción a la economía y a la sociedad del saber". Revista Internacional de Ciencias Sociales, No. 171. D. Foray, Ed. (2002)

2. D. Robinson, "Condiciones de contratación y de empleo del personal académico en Australia, Canadá, Estados Unidos, Nueva Zelanda y Reino Unido". Educational International: http://www.ei-ie.org/highereducation/file/ (2006).

3. J.M. Podolny, "Status Signals. A Sociological Study of Market Competition". Google Books: http://books.google.com.mx/ (2005). 
4. J.M. Naredo, "Sobre el origen, el uso y el contenido del término sostenible". Recuperado el 26 de noviembre de 2011 en Ciudades para un futuro sostenible: http://habitat.aq.upm.es/cs/p2/a004.html (1997).

5. W. Chakroun, F. Gribaa, A. Tounés, "A spatio-temporal odyssey around the concepts of sustainable development and corporate social responsibility: boundaries to be determined?" En World Conference Proceedings, (pag. 1-23). Washington (2010).

6. F.N. Kerlinger, H.B. Lee, "Investigación del comportamiento. Métodos de investigación en ciencias sociales" (Cuarta ed.). México: Mc Graw Hill. (2002).

7. UNCSD, "Agenda 21". Rio de Janeiro: United Nation Commission on Sustainable Development. Conference on Environment \& Development (1992).

8. J. Barbieri, I.F. Gouveia de Vasconcelos, T. Andreassi, R. Carvalho de Vasconcelos, "Inovaçào e sustentabilidade: novos modelos e proposiçôes". Revista de Administraçâo de Empresas, 50(2), 146-154 (2010).

9. UNCSD, "Indicators of sustainable development: guidelines and methodologies". New York: United Nations Commission on Sustainable Development. (2001)

10. S. Pfahl, "Institutional sustainability". International Journal of Sustainable Development, Vol. 8, Nos. 1/2, 80-96 (2005).

11. J. B. Coblentz, "Organizational Sustainability: The Three Aspects that Matter". ERNWACA's first Strategy Session, page. 4 (2002).

12. K. L. Carlenton, "Framing sustainable performance with six-P". Performance Improvement, 48(8), 37-48 (2009).

13. M. Van Marrewijk, "Concepts and definitions of CSR and Corporate Sustainability: Between agency and Communion". Journal of Business Ethics, 44, 95-105 (2003).

14. J.J. Urrieta, "Rutinas y complejidad de las organizaciones públicas modernas". Economía y Sociedad, XII (20), 156-176 (2007).

15. WACOSS, "Housing and sustainable communities indicators project". Western Australia. . (2002).

16. M. Redclift, "Sustainable Development. Exploring the contradiction". London: Taylor \& Francis Group (1987).

17. I. Omann, J.H. Spangenberg, "Assessing Social Sustainability. The Social Dimension of Sustainability in a Socio-Economic Scenario". 7th Biennial Conference of the International Society for Ecological Economics, (page. 1-20). Sousse, Tunisia (2002).

18. M. Achkar, "Indicadores de sustentabilidad". En M. Achkar, V. Canton, R. Cayssials, A. Domínguez, G. Fernández, \& F. Pesce, Ordenamiento ambiental del territorio (pág. 104). Montevideo: Comisión Sectorial de Educación Permanente (2005).

19. H. E. Daly, "Steady-State Economics: Concepts, Questions, Policies". Ecological Economics (6), 333-338. (1992).

20. R. Goodland, "The concept of enviromental sustainability". Annual Review of Economic and Systematics, 26, 1-24 (1995).

21. D. Doane, A. MacGillivray, "Economic Sustainability. The business of staying in business". New Economics Foundation (2001).

22. D.C. North, "Institutions, Institutional Change and Economic Performance". Cambridge: Cambridge University Press (1991).

23. S. Anand, A. Sen, "Human Development and Economic Sustainability". World Development, 28(12), 2019-2049 (2000).

24. J. Pfeffer, G. Salancik, "The external control of organizations. A resource dependence perspective". Nueva York: Harper \& Row Publishers (1978). 
25. A. Hillman, T. Dalziel, "Boards of Directors and Firm Performance: Integrating Agency and Resource Dependence". The Academy of Management Review, 28(3), 383-396 (2003).

26. J. Elkington, "Cannibals with forks: the triple bottom line of 21st century business". Oxford: Capstone Publishing Ltd. (1997).

27. J. Firestone, H. Hadders, S. Cavaleri, "Measuring organizational sustainability performance: the Adaptive Quadruple Bottom Line Scorecard". s.l., Academic Conferences Ltd, pp. 124-131 (2009).

28. B.E. Gutiérrez, C. Martínez, "Dimensiones de sustentabilidad en instituciones de educación superior. Propuesta para un centro de investigación". Revista de la Educación Superior, Octubre - Diciembre, XXXVIII (4) (152), pp. 113-124 (2009).

29. R. Garza, J.G. Medina, "La sustentabilidad en las instituciones de educación superior. Una visión holística". Monterrey: La \& Go (2010).

30. A. Wigmore, M. Ruiz, "Sustainability assessment in higher education institutions. The STARS system". Ramon Llull Journal of Applied Ethics, pp. 25-42 (2010).

31. D.A. Aaker, V., Kumar, G. Day, "Marketing Research". New York: John Wiley and Sons (2011).

32. P. Morales, "El análisis factorial en la construcción e interpretación de test, escalas y cuestionarios". Recuperado el 30 de agosto de 2012, de Universidad Pontificia Comillas: http://www.upcomillas.es/personal/peter/investigacion/AnalisisFactorial.pdf (2011).

33. T.P. Hogan, "Pruebas Psicológicas: una introducción práctica" (Primera ed.). México: Manual Moderno (2004).

34. C. García, "Como Investigar en Psicología" (1a ed.). México: Trillas (2009).

35. L.J. Cronbach, "Coefficient alpha and the internal structure of the test". Psychometrica, 6(2), 298 - 334 (1951).

36. J.M. Drees, P. Pursey, "Synthesizing and Extending Resource Dependence Theory: A Meta-Analysis". Journal of Management (39), 1666-1698 (2013). 

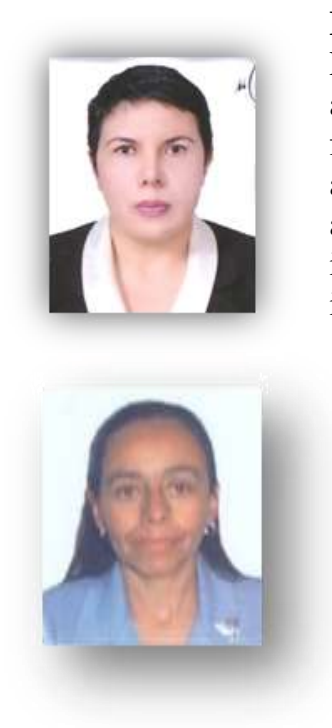

First Author is professor at the Universidad Autónoma del Estado de México. She received her master's degree in administration and her $\mathrm{PhD}$ in Economic Administrative Sciences from the Universidad Autónoma del Estado de México in 2004 and 2013, respectively. She is the author of three journal papers and has written three book chapters. Her current research areas include issues of corporate social responsibility and sustainability in organizations.

Second Author is professor at the Universidad Autónoma del Estado de México. She received her master's degree in administration from Universidad Autónoma del Estado de México in 1998, and her $\mathrm{PhD}$ in administrative sciences from the Universidad Nacional Autónoma de México in 2002. She is the author of more than ten journal papers and has written more than five book chapters and two books. Her current research interests include intellectual capital issues. She is a member of National System of Investigators.

\section{Caption list}

Table 1. Sustainability components

Table 2. Principal components extracted (varimax rotation, $n=239$ )

Table 3. Components and items of the OSD-39

Figure 1. Construction and validation process of OSD 